\title{
Trade in Health Services in the ASEAN Region
}

\author{
By Jutamas Arunanondchai and Carsten Fink ${ }^{*}$
}

\begin{abstract}
Promoting quality health services to large population segments is a key ingredient to human and economic development. At its core, healthcare policymaking involves complex trade-offs between promoting equitable and affordable access to a basic set of health services, creating incentives for efficiencies in the healthcare system, and managing constraints in government budgets. International trade in health services influences these trade-offs. It presents opportunities for cost savings and access to better quality care, but it also raises challenges in promoting equitable and affordable access. Drawing on a research project of the ASEAN Economic Forum, this paper offers a discussion of trade policy in health services for the ASEAN region. It reviews the state of healthcare in the region, existing patterns of trade, and remaining barriers to trade. The paper also identifies policy measures that could further harness the benefits from trade in health services and address potential pitfalls that deeper integration may bring about.
\end{abstract}

\section{World Bank Policy Research Working Paper 4147, March 2007}

The Policy Research Working Paper Series disseminates the findings of work in progress to encourage the exchange of ideas about development issues. An objective of the series is to get the findings out quickly, even if the presentations are less than fully polished. The papers carry the names of the authors and should be cited accordingly. The findings, interpretations, and conclusions expressed in this paper are entirely those of the authors. They do not necessarily represent the view of the World Bank, its Executive Directors, or the countries they represent. Policy Research Working Papers are available online at http://econ.worldbank.org.

\footnotetext{
* Jutamas Arunanondchai is a Senior Researcher at the Fiscal Policy Research Institute Foundation, Bangkok, Thailand. Carsten Fink is a Senior Economist at the World Bank Institute. This paper is based on a research project on trade in health services undertaken by the ASEAN Economic Forum research network and supported by the World Bank Institute. Comments by Rudolf Adlung, Nick Drager and Karin Timmermans are gratefully acknowledged.
} 


\section{Introduction}

The performance of a country's health sector is critical for the well-being of its citizens. Promoting quality health services to large population segments is a key ingredient to human development. It is also grounded in basic economic considerations. Caring for sick workers preserves a country's stock of human capital, laying the foundation for sustained economic growth. The provision of health services also has important public good characteristics, in particular when it comes to containing the spread of infectious diseases such as HIV/AIDS, tuberculosis and malaria.

Given the centrality of healthcare to human well-being, policy reform discussions in the health sector tend to be of a sensitive nature-be it in poor or rich countries. The provision of health services is typically not regarded as an economic transaction in the way the purchase of a car or a train ticket would be. Indeed, many countries have inscribed a basic right to healthcare in their constitutions, sometimes mandating the provision of services free of charge. Trade policy discussions in the health sector add another layer of sensitivity. Health services are commonly not viewed as a tradable commodity that can be subject to global market forces. The idea of foreign medical institutions providing essential services to the local population may be perceived as encroaching on national sovereignty.

Notwithstanding these sensitivities, healthcare policy does involve serious economic choices. Today, medical technologies exist that can completely cure many ailments and provide effective treatment against others. Yet bringing diagnostic tools, advice, clinical treatment, drugs and vaccines to patients requires resources that are scarce in every country and that can be employed elsewhere in the economy. Few countries can afford state-of-the-art healthcare for every citizen. Choices about what kind of health services are provided to which segments of the population have to be made-explicitly or implicitly. Generally, these choices will depend on a country's level of economic development. To illustrate, if Malaysia were to spend the same per-capita amount of money on healthcare as Switzerland, Malaysia's health expenditure would be roughly equal to its gross domestic product (GDP), leaving no money for food, housing, clothing, or transportation. For Thailand, Indonesia, and Cambodia, health expenditure would be, respectively, twice, five times, and thirteen times the value of national GDP. ${ }^{1}$

No country leaves the provision of health services entirely to market forces. Governments intervene in a number of ways, by directly providing health services, financing healthcare through public insurance mechanisms, and regulating private health services and private health insurance. At its core, healthcare policymaking involves complex trade-offs between promoting equitable and affordable access to a basic set of health services at minimum quality, creating incentives for efficiencies in the healthcare system, and managing constraints in central and state-level government budgets. International trade in health services influences these trade-offs. It can present opportunities for cost savings and access to better quality care, but it can also raise challenges in promoting equitable and affordable access.

\footnotetext{
${ }^{1}$ According to the World Health Organization (2005), Switzerland spent \$4,219 per person on health in 2002. Data on ASEAN countries' population and GDP are available from the World Bank's World Development Indicators.
} 
Against, this background this paper offers a discussion of trade policy in health services for the ASEAN region. It draws on a set of national research studies that were conducted by researchers of the ASEAN Economic Forum. These studies covered 7 of the 10 ASEAN countries: Cambodia, Indonesia, Laos, Malaysia, the Philippines, Thailand, and Vietnam. ${ }^{2}$

As will be shown later in this paper, trade in health services is already an important phenomenon in the ASEAN region. To a large extent, this trade occurs outside the framework of existing trade agreements. At the same time, ASEAN governments have established a framework for progressively liberalizing trade in services and, in particular, have identified healthcare as a priority sector for region-wide integration. Therefore, a key aim of this paper is to identify policy measures that would harness the benefits from trade in health services and address potential pitfalls that deeper integration may bring about.

The paper is structured as follows. To set the scene, the next section will offer a brief overview of the state of healthcare across the ASEAN region, focusing on the roles of the public and private sectors and the performance of the healthcare system in terms of access and quality. Section III will introduce the concept of international trade in health services and review the patterns of existing trade in the region. Section IV will document remaining barriers to trade in health services. Section V will outline the gains that further trade liberalization could offer and also point to possible pitfalls that expanded trade may hold. Section VI discusses several policy implications and makes several recommendations for policy initiatives that ASEAN countries could pursue. The final section offers concluding remarks.

\section{The state of healthcare in the ASEAN region}

This section reviews the performance of the healthcare sector across the seven ASEAN countries studied thus far and problems that remain. We focus on four dimensions of healthcare performance: (i) accessibility of basic healthcare services; (ii) provision of healthcare by the public sector, private sector and NGOs; (iii) sources of healthcare financing; and (iv) quality of healthcare services.

\section{Accessibility of healthcare services}

Unsurprisingly, accessibility of healthcare services in the ASEAN region varies significantly with countries' level of economic development. At the same time, income cannot explain everything. Countries' histories and policies also play an important role.

Data from the World Health Organization (WHO) on immunization coverage among 1-year olds, antenatal care coverage and the proportion of births attended by skilled health personnel are revealing in terms of access to healthcare in the ASEAN region (Table 1). The health service coverage figures of Malaysia, Singapore and Thailand are comparable to those of the United

\footnotetext{
${ }^{2}$ See Chea (2005) for Cambodia, Leebouapao (2004) for Laos; Akhmad (2005); Abidin, Alavi, and Kamaruddin (2005) for Malaysia; Avila and Manzano (2005); Arunanondchai (2005) for Thailand; and Thang (2005) for Vietnam. In view of its economic importance, Singapore is also included in parts of this paper, drawing on information available from the seven country studies as well as publicly available data.
} 
Kingdom and the US. Interestingly, Vietnam also performs relatively well compared to the rest of the group. It enjoys higher immunization coverage and higher proportion of births attended by skilled health personnel than the Philippines and Indonesia, although not for antenatal care. As expected, Cambodia and Lao PDR lag behind others countries in its health service coverage.

Table 1: Healthcare services coverage

\begin{tabular}{|c|c|c|c|c|c|c|c|}
\hline \multirow[t]{2}{*}{ Country } & \multicolumn{3}{|c|}{$\begin{array}{c}\text { Immunization coverage (\%) among } \\
1 \text {-year-olds }\end{array}$} & \multicolumn{2}{|c|}{$\begin{array}{l}\text { Antenatal care } \\
\text { coverage }^{b}\end{array}$} & \multicolumn{2}{|c|}{$\begin{array}{l}\text { Births attended by skilled } \\
\text { health personnel }\end{array}$} \\
\hline & $\begin{array}{c}\text { Measles } \\
2003\end{array}$ & $\begin{array}{c}\text { DTP3 } \\
2003\end{array}$ & $\begin{array}{c}\text { НерВ3 } \\
2003\end{array}$ & & & $(\%)$ & Year \\
\hline Cambodia & 65 & 69 & 0 & 44 & 2000 & 32 & 2000 \\
\hline Indonesia & 72 & 70 & 75 & 97 & 2003 & 66 & 2003 \\
\hline Lao PDR & 42 & 50 & 50 & 44 & 2001 & 19 & 2001 \\
\hline Malaysia & 92 & 96 & 95 & $\ldots$ & $\ldots$ & 97 & 2001 \\
\hline Philippines & 80 & 79 & 40 & 94 & 2003 & 60 & 2003 \\
\hline Singapore & 88 & 92 & 92 & $\ldots$ & $\ldots$ & 100 & 1998 \\
\hline Thailand & 94 & 96 & 95 & $\ldots$ & $\ldots$ & 99 & 2002 \\
\hline Vietnam & 93 & 99 & 78 & 70 & 2002 & 85 & 2002 \\
\hline United Kingdom ${ }^{\mathrm{c}}$ & 80 & 91 & 0 & $\ldots$ & $\ldots$ & 99 & 1998 \\
\hline United States $^{\mathrm{c}}$ & 93 & 96 & 92 & $\ldots$ & $\ldots$ & 99 & 1997 \\
\hline
\end{tabular}

Notes:

...Data not available or not applicable

a. World Health Organization, Department of Immunization Vaccines and Biologicals, Vaccine Assessment and Monitoring

Team. (http//www.who.int/vaccines-surveillance, accessed on 16 April 2005)

b. The World Health Report 2005: make every mother and child count. Geneva, World Health Organization, 2005.

(http://www.who.int/whr/2005/en/index.html)

c. The figures for the UK and USA have been included for purposes of comparison.

A similar picture emerges when comparing the number of hospital beds across the seven ASEAN countries studied (Table 2). The Thais, Malaysians and Singaporeans enjoy the highest number of beds per population. Vietnam also performs relatively well. Despite this, there are signs that the healthcare infrastructure in Vietnam is not being used efficiently. Thang (2005) describes heavy reliance on hospitals for primary treatments and high inpatient admission rates relative to other countries in the region, indicating over-utilization of hospital beds. The number of hospital beds per population in Cambodia and Indonesia are respectively one-third and one-fourth that of Thailand.

In Thailand, Indonesia, Vietnam, Cambodia and Laos, state-funded primary healthcare centers (HCs) are the main providers of basic healthcare services to the majority of the people. ${ }^{3}$ Thailand enjoys the highest number of HCs per population in this group. HCs in Cambodia and Laos are reported to be ill-equipped and ill-staffed due to insufficient funding. Poor access to

\footnotetext{
${ }^{3}$ The services typically include preventive, ambulatory, inpatient services and referral services.
} 
HCs in Laos is largely due to the termination of the cooperative farming system in the early 1990s which led to the closure of associated health facilities. ${ }^{4}$

Table 2: Number of hospitals, hospital beds, and health centers

\begin{tabular}{|c|c|c|c|c|c|c|c|c|}
\hline & $\begin{array}{c}\text { Thailand } \\
\text { (2001) }\end{array}$ & $\begin{array}{c}\text { Malaysia } \\
\text { (2001) }\end{array}$ & $\begin{array}{c}\text { Singapore } \\
\text { (2001) }\end{array}$ & $\begin{array}{c}\text { Indonesia } \\
(2001)\end{array}$ & $\begin{array}{c}\text { Philippines } \\
\text { (2002) }\end{array}$ & $\begin{array}{c}\text { Vietnam } \\
\text { (2002) }\end{array}$ & $\begin{array}{c}\text { Cambodia } \\
\text { (2002) }\end{array}$ & $\begin{array}{c}\text { Laos } \\
(2002)\end{array}$ \\
\hline $\begin{array}{l}\text { Total no. of } \\
\text { hospitals }\end{array}$ & 1,409 & $\begin{array}{l}345 \\
\text { (g) }\end{array}$ & 29 & 935 & 1,738 & 987 & 1,073 & 150 \\
\hline No. of beds & $\begin{array}{c}135,303 \\
\text { (a) }\end{array}$ & 44,120 & 11,840 & 109,948 & 85,166 & $\begin{array}{l}250,000 \\
\text { (d) }\end{array}$ & 9,800 & $\begin{array}{c}6,315 \\
\text { (e) }\end{array}$ \\
\hline $\begin{array}{l}\text { Beds per } \\
10,000 \text { pop }\end{array}$ & $\begin{array}{l}21.8 \\
\text { (b) }\end{array}$ & 18.8 & 29.0 & 5.2 & 10.8 & 14.8 & 7.4 & 9.2 \\
\hline $\begin{array}{l}\text { Total no. of } \\
\text { health } \\
\text { centers } \\
\text { (HCs) }\end{array}$ & $\begin{array}{l}10,037 \\
\text { (f) }\end{array}$ & $\ldots$ & $\ldots$ & $\begin{array}{c}7277 \text { PHC } \\
21587 \\
\text { SPHC } \\
\text { (h) }\end{array}$ & $\ldots$ & $\begin{array}{l}10,000 \\
\text { approx. }\end{array}$ & $\ldots$ & 644 \\
\hline $\begin{array}{l}\text { HCs per } \\
10,000 \text { pop }\end{array}$ & 1.6 & $\ldots$ & $\ldots$ & $\begin{array}{c}1.4 \\
\text { incl. } \\
\text { SPHC }\end{array}$ & $\ldots$ & 1.2 & $\ldots$ & $\ldots$ \\
\hline $\begin{array}{l}\text { Total pop in } \\
\text { thousands } \\
\text { (c) }\end{array}$ & 61,997 & 23,467 & & $211,895.4$ & $78,681.2$ & $80,897.8$ & $13,274.8$ & 5,537 \\
\hline
\end{tabular}

Notes:

...Data not available or not applicable

(a) Health Resources by WHO (1999)

(b) Assuming that the number of hospital beds remains at the 1999 level.

(c) Calculated from "World Population Prospects: The 2004 Revision Population Database".

(d) Approximate figure taken from STAT-USA Market Research Report at http://strategis.ic.gc.ca/epic/internet/inimrri.nsf/en/gr108259e.html.

(e) Figure includes 1,241 beds at health centers.

(f) The figure does not include Primary Health Care Units which are made up of trained village volunteers.

(g) Comprising of general hospitals, district hospitals, special medical institutions which are all public and other private hospitals.

(h) PHC and SPHC are Primary Health Centers and Supporting Primary Health Centers respectively.

Looking at countries' stock of medical personnel, the Philippines and Singapore stand out from the rest of the group in terms of the number of physicians and nurses per 10,000 inhabitants (Table 3). ${ }^{5}$ Thailand also enjoys a relatively high number of nurses per population, although

\footnotetext{
${ }^{4}$ According to Leebouapao (2004), more than 700 health centers were closed and the health system almost came to a collapse. The Northern region was the worse hit. As of 2004, 29.1 percent of the villages were at least 16 kilometers away from the nearest health center. To improve access to essential drugs to the poor, so-called Drug Revolving Funds (DRF) were established in the mid-1990s. The system is self-funded through revenues received from the sale of drugs to patients (although poor people are exempted from user charges). The performance of the DRFs has been mixed, as the level of poverty in a district typically dictates the viability of DRFs.

${ }^{5}$ One must be careful when interpreting the numbers in Table 3 since the figures available are often exaggerated. Many of the registered health personnel are no longer working or work abroad (see Section III). Moreover, the figures refer to different years. However, given the long training period for physicians, their numbers tend to be relatively stable through time.
} 
there are complaints of shortages of skilled (diploma level) nurses. Despite better access to healthcare service, the number of physicians per population in Thailand is lower than Vietnam and Laos. In Vietnam, due to limited number of medical facilities, many medical graduates cannot find work and take on the role of nurses. ${ }^{6}$

Table 3: Number of registered health personnel

\begin{tabular}{|c|c|c|c|c|c|c|c|c|}
\hline & $\begin{array}{c}\text { Malaysia } \\
\text { (2000) } \\
\text { (d) }\end{array}$ & $\begin{array}{c}\text { Singapore } \\
\text { (2001) } \\
\text { (m) }\end{array}$ & $\begin{array}{l}\text { Thailand } \\
\text { (2000) } \\
\text { (c) }\end{array}$ & $\begin{array}{c}\text { Indonesia } \\
\text { (2003) } \\
\text { (e) }\end{array}$ & $\begin{array}{c}\text { Philippines } \\
\text { (2003) }\end{array}$ & $\begin{array}{c}\text { Vietnam } \\
\text { (2002) }\end{array}$ & $\begin{array}{c}\text { Cambodia } \\
\text { (2001) } \\
\text { (f) }\end{array}$ & $\begin{array}{c}\text { Laos } \\
(1996) \\
(\mathrm{m})\end{array}$ \\
\hline $\begin{array}{l}\text { Total no. of } \\
\text { physicians* }\end{array}$ & 16,468 & 5747 & $\begin{array}{l}22,435 \\
\text { (a) }\end{array}$ & $\begin{array}{c}48531 \\
(\mathrm{~g})\end{array}$ & 101,758 & 45,702 & $\begin{array}{c}2,055 \\
\text { (h) }\end{array}$ & 2812 \\
\hline $\begin{array}{l}\text { Physician } \\
\text { per10,000 pop }\end{array}$ & 7.1 & 14.0 & 3.6 & 2.2 & 12.7 & 5.6 & 1.6 & 5.9 \\
\hline No. of dentists & 2,001 & 1087 & 6,966 & 9,177 & 45,321 & NA & NA & 196 \\
\hline $\begin{array}{l}\text { Dentist per } \\
10,000 \text { pop }\end{array}$ & 0.9 & 2.6 & 1.1 & 0.4 & 5.7 & NA & NA & 4.1 \\
\hline $\begin{array}{l}\text { No. of } \\
\text { pharmacists }\end{array}$ & 2,801 & 1141 & 10,354 & NA & 49,117 & 6,148 & NA & NA \\
\hline $\begin{array}{l}\text { Pharmacist per } \\
10,000 \text { pop }\end{array}$ & 1.2 & 2.8 & 1.7 & NA & 6.1 & 0.8 & NA & NA \\
\hline No. of nurses & 39,890 & 17,398 & $\begin{array}{l}119,651 \\
(\mathrm{k})\end{array}$ & $\begin{array}{l}81,190 \\
\text { (j) }\end{array}$ & $\begin{array}{l}354,544 \\
\text { (b) }\end{array}$ & 47,006 & $\begin{array}{l}11,105 \\
\text { (i) }\end{array}$ & 4931 \\
\hline $\begin{array}{l}\text { Nurse per } \\
10,000 \text { pop }\end{array}$ & 19.3 & 42.4 & 19.3 & 3.8 & 44.2 & 5.8 & 8.5 & 10.3 \\
\hline
\end{tabular}

Notes:

The population estimates for Indonesia, Cambodia, the Philippines and Vietnam are calculated from UN's "World Population Prospects: The 2004 Revision Population Database”.

Figures for Lao PDR are not available.

(a) $75 \%$ are medical specialists.

(b) A substantial share of registered nurses in the Philippines work abroad (see Section III).

(c) From Thammarangsi (2003a)

(d) From $8^{\text {th }}$ Malaysian Plan (2000) p.489

(e) From Indonesia's Ministry of Health (2001 figures for nurses).

(f) Ministry of Health's employees only

(g) $23 \%$ are specialists

(h) Physicians are supplemented by 1,425 medical assistants.

(i) In Cambodia, $44.8 \%$ are primary nurses and 55.2 are secondary nurses.

(j) Only 13\% of nurses in Cambodia carry the 3-Year Diploma degree, the rest carry high school diplomas.

(k) The figure comprises nurses of various skill levels (from diploma graduates to college graduates).

(l) Global Health Atlas of infectious diseases. World Health Organization. Data updated with recent information from Regional Office websites and publications.

(m) Data from WHO Global Atlas of the Health Workforce.

\footnotetext{
${ }^{6}$ In the 1980s, Vietnam had cooperation pacts with countries in Africa, e.g. Mozambique, Angola, Lybia, Algeria, Madagascar etc., whereby surplus medical doctors from Vietnam were sent abroad under the pact.
} 
Finally, there is not only substantial variation in access levels across countries in the ASEAN region, but also within individual countries. In particular, those who live in urban areas enjoy better access to healthcare services - infrastructure as well as personnel — than those in the rural areas. For example, in Cambodia, Indonesia, and Thailand, districts with the best access conditions have 10 times or more the number of physicians per population than districts with the worst access conditions. In Indonesia, $47 \%$ of all health personnel are located in Java. The ratio of hospital beds per population in Jakarta is 1:621 compared to 1:3,906 in Lampung (Akhmad, 2005).

\section{Provision of healthcare}

In most ASEAN countries, health services are predominately provided by public hospitals (Table 4). At the same time, the private sector plays an increasingly important role in the region's richer economies. The share of hospitals belonging to the private sector ranges between 30-65 percent in Indonesia, Malaysia, the Philippines, Singapore, and Thailand, compared to 0-2 percent in Laos and Vietnam. Private hospitals are smaller in size and tend to be located in urban areas, serving middle- to high-income patients as well as foreign patients. Several private hospitals in Thailand, Singapore and Malaysia offer advanced specialist services. They are often better equipped with advanced medical technologies and personnel than public hospitals. ${ }^{7}$ In poorer ASEAN economies, the role of the private sector entry has been limited to the operation of clinics and pharmacies.

Table 4: Public versus private sector healthcare provision

\begin{tabular}{l|c|c|c|c}
\hline & \multicolumn{2}{|c|}{ Hospitals } & \multicolumn{2}{c}{ Beds } \\
& $\begin{array}{c}\text { Public } \\
(\%)\end{array}$ & $\begin{array}{c}\text { Private } \\
(\mathbf{\% )}\end{array}$ & $\begin{array}{c}\text { Public } \\
\mathbf{( \% )}\end{array}$ & $\begin{array}{c}\text { Private } \\
\mathbf{( \% )}\end{array}$ \\
\hline Cambodia (2002) & $\ldots$. & $\ldots$ & 78.6 & 21.4 \\
Indonesia (2001) & 56 & 44.0 & 63.3 & 36.7 \\
Laos (2002) & 100 & 0 & 100.0 & 0 \\
Malaysia (2001) & 35.1 & 64.9 & 78.4 & 21.6 \\
Singapore (2004) & 44.8 & 55.2 & 74.4 & 25.6 \\
Philippines (2002) & 38.0 & 62.0 & 53.3 & 46.7 \\
Thailand (2001) & 69.1 & 30.9 & $\ldots$ & $\ldots$ \\
Vietnam (2002) & 98.3 & 1.7 & $\ldots$ & $\ldots$ \\
\hline
\end{tabular}

Notes:

... Data not available

Figures taken from the Ministries of Public Health in the countries concerned.

Since private healthcare providers pay higher wages than the public sector, the growth of the private sector caused a migration of medical doctors, specialists, pharmacists, nurses and other allied health personnel from the public to the private sector in all countries. This has led some countries, e.g. Cambodia and Thailand, to impose public service requirements. ${ }^{8}$ The share of health personnel in the private sector typically correlates with the business cycle-expanding

\footnotetext{
${ }^{7}$ For examples, in Malaysia in 1999, 23 of 27 MRI facilities; 67 out of 86 CT scanners; 67 percent of physicians; 66 percent of surgeons and 80 percent of obstetricians and gynecologists worked in the private sector.

${ }^{8}$ In Cambodia, all healthcare professionals are not allowed to work in the private sector unless it is off-working hours.
} 
during economic upswing as the demand for private healthcare rises and contracting during economic downturns.

Thailand's private medical services market is further segmented into those that participate in public health insurance schemes and those that cater to foreign visitors and expatriates (see Section V). The latter offer the most sophisticated and highest quality medical services.

In Vietnam, Cambodia and Laos, the high proportion of public provision is a legacy of the past political regime. In Vietnam, the deregulation of the healthcare sector in 1986 resulted in only 17 private hospital setups. The 1994 deregulation in Cambodia did not attract many private hospitals either. As mentioned, private participation in both countries has been mainly in the form of drug outlets, pharmacies and clinics. This has led to improved drug supplies and distribution, particularly in Laos where public health facilities are inaccessible in many areas.

In Malaysia, the government has made a conscious effort to contract out to the private sector certain auxiliary health services, such as cleaning, laboratory tests, drug distribution and others. This was done to bring down medical costs, although there are indications that this form of outsourcing has actually increased costs (Abidin, Alavi, and Kamaruddin, 2005).

Public healthcare is subsidized in all of the ASEAN countries studied, although to varying degrees. In particular, the ability to subsidize is constrained by governments' budgetary resources. The Malaysian government can afford to subsidize most public services (only 5\% of the total expense is covered by fees). The Thai government also subsidizes the public provision through the national tax-funded 'Universal Care' scheme. In the poorer ASEAN countries, user fees were introduced because the government could not afford to fully subsidize the provision of health services.

\section{Healthcare financing}

While per capita expenditure on health is closely correlated with income, there is no such systemic variation for the share of health expenditure in GDP and the share of government spending devoted to health (Table 5).

Table 5: Healthcare expenditure in 2002

\begin{tabular}{|c|c|c|c|c|}
\hline & $\begin{array}{l}\text { Total expenditure } \\
\text { on health } \\
\text { (\% of gross domestic } \\
\text { product) }\end{array}$ & $\begin{array}{c}\text { General government } \\
\text { expenditure on health } \\
\text { (\% of total government } \\
\text { expenditure) }\end{array}$ & $\begin{array}{l}\text { Per capita total } \\
\text { expenditure on health } \\
\text { (international dollars) }^{\text {a }}\end{array}$ & $\begin{array}{c}\text { Per capita Gross } \\
\text { Domestic Product (on } \\
\text { a PPP basis }{ }^{\mathbf{b}} \text {, } \\
\text { international dollars) }\end{array}$ \\
\hline Cambodia & 12.0 & 18.6 & 192 & 2,081 \\
\hline Lao PDR & 2.9 & 8.7 & 49 & 1,738 \\
\hline Indonesia & 3.2 & 5.4 & 110 & 3,200 \\
\hline Malaysia & 3.8 & 6.9 & 349 & 9,183 \\
\hline Philippines & 2.9 & 4.7 & 153 & 4,202 \\
\hline Singapore & 4.3 & 5.9 & 1,105 & 24,843 \\
\hline Thailand & 4.4 & 17.1 & 321 & 6,909 \\
\hline Vietnam & 5.2 & 6.1 & 148 & 2,347 \\
\hline
\end{tabular}


Notes:

a The World Health Report 2005, World Health Organization, 2005. (http://www.who.int/whr/2005/en/index.html)

${ }^{\mathrm{b}}$ World Development Indicators, The World Bank.

As expected, Malaysia, Singapore and Thailand have the highest per capita expenditure on healthcare. However, Cambodia spends as much as 12 percent of GDP on healthcare, far more than other countries in the group. The Thai and Cambodian governments devote over 17 percent of public spending to healthcare-again, far more than other governments in the region.

In Singapore, Laos, Cambodia, Philippines and Indonesia, most of the healthcare expenditure comes from private sources, the majority of which is out-of-pocket (Table 6). In Cambodia and Laos, a substantial share of healthcare funding also comes from foreign donors and NGOs. Only in Malaysia and Thailand is the public sector the most important source of healthcare financing.

Table 6: Sources of healthcare financing (in percent)

\begin{tabular}{|c|c|c|c|c|c|c|c|c|}
\hline & $\begin{array}{c}\text { Singapore } \\
(2001)\end{array}$ & $\begin{array}{l}\text { Thailand } \\
\text { (2002) }\end{array}$ & $\begin{array}{c}\text { Malaysia } \\
(2001)\end{array}$ & $\begin{array}{c}\text { Vietnam } \\
\text { (1998) }\end{array}$ & $\begin{array}{c}\text { Cambodia } \\
\text { (2002) }\end{array}$ & Indonesia & $\begin{array}{c}\text { Laos } \\
(1999)\end{array}$ & $\begin{array}{c}\text { Philippines } \\
\text { (2003) }\end{array}$ \\
\hline $\begin{array}{l}\text { Government (including } \\
\text { subsidized public } \\
\text { insurance where } \\
\text { applicable) }\end{array}$ & 33.5 & 67.5 & 53.7 & 19.5 & 8.8 & & 9.0 & 37.5 \\
\hline Social Insurance & & & & & & & & 7.8 \\
\hline $\begin{array}{l}\text { Private Sources } \\
\text { of which are: }\end{array}$ & 66.5 & 32.5 & 46.3 & 80.5 & 72.9 & & 55.7 & 54.8 \\
\hline $\begin{array}{l}\text { Out-of-Pocket } \\
\text { Private Insurance } \\
\text { Health Maintenance } \\
\text { Organization }\end{array}$ & 97.0 & $\begin{array}{l}84.6 \\
10.0\end{array}$ & $\begin{array}{c}92.8 \\
7.2\end{array}$ & & & $\begin{array}{l}70.0 \\
<2.0\end{array}$ & 60.0 & $\begin{array}{c}78.1 \\
2.4 \\
7.3\end{array}$ \\
\hline NGOs & & & & & 18.2 & & 35.2 & \\
\hline
\end{tabular}

Sources: Philippines’ National Statistical Coordination Board (PSY 2003); WHO World Health Report.

Notwithstanding the overall strong reliance on out-of-pocket financing, public health insurance is playing an increasing role in a number of ASEAN countries. In Thailand, 80.4 percent of the population is covered by the 'Universal Care' scheme, which was introduced in 2001. By 2002, this mechanism reduced private out-of-pocket spending of the uninsured households by 14.2 percent, while increasing government spending on health by 24.4 percent. In Indonesia, 27.6 percent of the population is covered by various public health insurance schemes. Vietnam has compulsory public health insurance for civil servants, state-owned enterprises and large private companies, covering around 12 percent of the population. In Cambodia, health insurance was introduced in 1991 but the system has not taken off due to its high cost and the lack of trust in public health facilities (Chea, 2005). The Philippine Government has initiated a compulsory National Health Insurance Program (NHIP) in 1995, targeting those in the lower income brackets. By 2002, 54 percent of the population was enrolled. 
In all countries, private health insurance plays a minor role in the private health care expenditure. For example, in Thailand, private insurance covers only $2 \%$ of those participating in health insurance. The main purchasers of these products are the middle and high income groups.

\section{Quality of healthcare services}

Concerns about the quality and regulation of private healthcare services have been expressed in Cambodia, Laos and Vietnam. ${ }^{9}$ In some circumstances, regulatory deficiencies have reportedly led to adverse health outcomes and a proliferation of informal medical practitioners. Public health facilities in these countries sometimes suffer from demoralized staff and insufficient medical equipment and drugs. In Vietnam, improper drug use has led to high levels of antibiotic resistance in the population. In Laos, despite the relatively large number of health personnel, training is considered to be inadequate, leading to high rates of misdiagnosis and maltreatment. ${ }^{10}$ In Cambodia, many private facilities use obsolete equipment and more than half do not hold a license from the Ministry of Health. ${ }^{11}$

In Malaysia, the Philippines, Singapore and Thailand high quality medical care is, in principle, available. A number of hospitals in these countries offer advanced specialized services, relying on modern equipment and highly qualified medical personnel. However, the best medical care is typically provided by private hospitals and can only be afforded by upper-middle-income and high-income patients. While the richer ASEAN countries have the basic regulatory infrastructure in place, monitoring and quality enforcement is often insufficient, leading to large variations in the quality of healthcare within countries.

To sum up, many of the healthcare indicators presented in this section vary closely with countries' level of economic development. Economic research suggests that causality goes both ways: healthier societies are more productive and richer countries can afford better healthcare. At the same time, differences in health performance are not fully accounted for by income. In particular, comparisons among ASEAN countries suggest that there is an important role for government policy to maximize resources available for healthcare and to ensure that those resources are effectively utilized.

\section{Current trade patterns in the ASEAN region}

The concept of trade in services goes beyond the traditional concept of trade, whereby physical goods move across borders from one country to another. Since most services require close

\footnotetext{
${ }^{9}$ See Chea (2005), Leebouapao (2004), and Thang (2005).

${ }^{10}$ There is only one medical school in Laos and six nursing schools. There are approximately 100 graduates in medicine, pharmacy and dentistry per year.

${ }^{11}$ It is estimated that there are approx. 896 legal pharmacies and almost 3 times the number of unlicensed ones; 500 legal clinics coexist with approx. 1,700 unlicensed clinics; and 13,000 village drug sellers. In all, approx. 87\% of drug stores are unlicensed.
} 
proximity between the supplier and consumer, trade discussions in services typically adopt a wide definition of what constitutes trade, involving the following four modes of supply:

- Mode 1: Cross-border supply. This mode of supply is akin to traditional goods trade, whereby suppliers and consumers are located in different countries. An example would be a 'telediagnosis' by a doctor in one country of a patient located in another country.

- Mode 2: Consumption abroad. International trade also takes place when the consumer moves to the country of the supplier. An example would be a patient temporarily traveling to a foreign hospital to undergo surgery.

- Mode 3: Commercial presence. This mode of supply describes the situation whereby producers, in the form of juridical persons (or companies), move to the country of the consumer. An example would be the establishment of a hospital, in which foreign investors hold a direct equity stake.

- Mode 4: Movement of individual service providers. As in the case of Mode 3, this mode of supply describes the situation whereby the producer moves to the country of the consumer, but the producer takes the form of a natural person (or individual). An example would be a nurse relocating to a foreign country and working there in a hospital. Mode 4 trade typically captures the movement of service workers that is of a temporary nature and does not involve permanent migration.

Remarkably, current trade patterns of countries in the ASEAN region involve all four modes of supply. This section will offer a brief overview of these patterns by individual modes.

\section{Mode 1: Cross-border supply}

Technological progress has enabled the remote supply of services that were previously nottradable across borders. Thus, firms in richer countries have been able to realize significant cost savings by outsourcing health-related service activities to poorer countries with lower wages. The one country in the ASEAN region that has been able to benefit from new export opportunities in this area is the Philippines. In particular, the Philippines have started to export medical transcription services to the United States. ${ }^{12}$ The Philippine's comparative advantage in medical transcription is explained mainly by its pool of educated English-speaking workers. Transcriptionists are usually medical school college graduates who work part time while preparing for the Philippine's board exams. The majority of the 25 companies exporting these services in 2004 were owned by US investors. Indeed, the Philippine Government offers special incentives for foreign direct investment (FDI) in this sector. While exports are still small in absolute value ( $\$ 10$ million in 2004 by a rough estimate), they hold substantial growth potential. For example, current exports to the United States still account for less than 1 percent of the \$13 billion spent on medical transcription in the United States per year.

\footnotetext{
${ }^{12}$ Under the services sectoral classification of trade agreements, medical transcription may not be considered a health but a business service.
} 


\section{Mode 2: Consumption abroad}

Several ASEAN countries have become significant exporters of "health tourism" services. These are chiefly Malaysia, Singapore, and Thailand. Table 7 presents information on export revenues and the number and origin of foreign patients for these countries. Thailand is the largest exporter in the region, followed by Malaysia and Singapore. Interestingly, in the case of Singapore and Malaysia, the majority of foreign patients come from other ASEAN countries (mainly Indonesia), whereas in the case of Thailand only 7 percent of foreign patients are from the ASEAN region. For Thailand, Japanese nationals account for the largest share of foreign patients.

Table 7: Export of health tourism services

\begin{tabular}{llll}
\hline & Export revenues & Number of patients & Origin of patients \\
\hline Malaysia (2003) & $\begin{array}{l}\text { RM 150 million } \\
\text { (\$40 million) }\end{array}$ & More than 100,000 & $\begin{array}{l}\text { 60 percent from Indonesia, 10 } \\
\text { percent from other ASEAN countries } \\
44 \text { percent from Indonesia, 20 } \\
\text { percent from Malaysia, 3 percent } \\
\text { from other ASEAN countries }\end{array}$ \\
& $\begin{array}{l}\text { \$420 million } \\
\text { Thailand }\end{array}$ & 210,000 & $\begin{array}{l}42 \text { percent from the Far East (mostly } \\
\text { Japan), 7 percent from ASEAN } \\
\text { countries }\end{array}$ \\
\hline
\end{tabular}

Sources: Singapore Tourism Board; Abidin, Alavi, and Kamaruddin (2005); Arunanondchai (2005).

The competitiveness of Malaysian, Singaporean, and Thai hospitals primarily stems from two factors. First, they can offer medical services at significantly lower price compared to industrial countries. As illustrated in Table 8, a coronary by-pass graft surgery in the United Kingdom is three times more expensive than in Malaysia. A hospital bed in the United States is almost 25 times more expensive than in Thailand. In view of the labor-intensiveness of hospital services, differences in labor costs are likely to account for much of the observed price differences. Second, hospitals in Malaysia, Singapore and Thailand have established a reputation for high quality services. In Thailand, service quality has been explicitly promoted by an accreditation system administered by a dedicated government agency - the Institute of Hospital Quality Improvement and Accreditation. Foreign patients mainly undergo treatments in the 9 private hospitals having the highest rankings for tertiary care in Thailand. A related aspect is that Malaysian, Singaporean and Thai hospitals can offer specialized services not available in other, especially poorer, ASEAN countries.

Table 8: Price comparisons (US\$, 2001)

\begin{tabular}{lcc}
\hline & $\begin{array}{c}\text { Coronary by-pass } \\
\text { graft surgery }\end{array}$ & $\begin{array}{c}\text { Single private } \\
\text { hospital room, } \\
\text { per night }\end{array}$ \\
\hline Malaysia & $\$ 6,315$ & $\$ 52$ \\
Singapore & $\$ 10,417$ & $\$ 229$ \\
Thailand & $\$ 7,894$ & $\$ 55$ \\
United Kingdom & $\$ 19,700$ & $\mathrm{n} / \mathrm{a}$ \\
\hline
\end{tabular}


For a number of medical treatments, hospitals from Malaysia, Thailand, and Singapore directly compete with each other. The price comparisons in Table 8 suggest strong competition, in particular, between Thailand and Malaysia. At the same time, hospitals in these three countries are differentiated by their medical expertise, the type of patients to which they cater, and certain ancillary services. For example, in order to attract foreign patients, some operators in Malaysia have started to offer integrated healthcare packages, involving not only medical treatment, but also transportation from and to the patient's home country, accommodation for family members and certain entertainment services.

Interest in developing the health tourism industry has also emerged in the Philippines. While health service exports are still in their infancy, the country benefits from a pool of well-qualified and English-speaking medical professionals. The Philippines have also developed expertise for certain specialized medical operations, such as cosmetic and laser eye surgeries. Hoping to build on these advantages, the Government included health tourism in its 2004 Investment Priorities Plan and is in the process of developing a business plan for the industry.

As for the low-income ASEAN countries, Vietnam also exports health tourism services, mainly to neighboring Cambodia. The number of foreign patients treated in Vietnam is thought to be small, but no precise statistical information is available. Indeed, most Cambodian patients seeking treatment abroad choose hospitals in Thailand and Singapore. Interestingly, several private hospitals in Cambodia make a business of facilitating treatment in foreign hospitals. Similar services are also provided by independent agents at Cambodia's borders.

\section{Mode 3: Commercial presence}

Health services in ASEAN countries are predominately provided by domestic medical institutions. Nonetheless, some foreign participation in the private sector healthcare segment can be found in six of the seven ASEAN countries studied (Laos being the only exception). Foreign service providers typically account for small shares of the healthcare market. For example, in Indonesia foreign hospitals are estimated to account for only one percent of total hospital beds (Timmermans, 2002). In the Philippines, only 2 of 19 health maintenance organizations (HMOs) are foreign-owned. In Thailand, foreign investors hold equity stakes in a number of hospitals, but they do not have a controlling interest, reflecting restrictions on foreign equity ownership (see Section III). Foreign investment is estimated to account for only 3 percent of total investment in private hospitals in Thailand. Some foreign presence also exists in Cambodia and Vietnam, though no information is available on the market shares of foreign hospitals. Across all countries in the region, foreign-owned healthcare facilities cater to the middle and upperincome population segments and are mostly found in urban areas.

Little comprehensive information exists on the origin of foreign investors. However, foreign investment appears to originate both from within and from outside the ASEAN region. In Cambodia, most foreign hospitals are of Chinese origin. Among AESAN countries, Singapore and Thailand, in particular, have emerged as outward investors in the healthcare sector. For 
example, Parkway Group Healthcare, the biggest investment group in the healthcare sector in Singapore, has set up joint ventures with hospitals in India, Indonesia, Malaysia, Sri Lanka, and the United Kingdom. Bumrungrad Hospital in Thailand has entered into management contracts with hospitals in Bangladesh and Myanmar, and has formed a joint venture with a hospital in the Philippines. Bangkok Hospital has established 12 branches in Southeast and South Asia, locating primarily in tourist towns.

\section{Mode 4: Movement of individual service providers}

The ASEAN region hosts two of the world's largest exporters of healthcare workers. The Philippines and Indonesia send large numbers of nurses and midwifes to countries around the world. This form of trade is driven by a growing supply of well-educated professionals in these two countries and shortages of healthcare workers in richer economies. Demographic pressures and rapidly rising healthcare costs in developed countries are likely to increase the demand for healthcare professionals from lower wage economies in future.

In the case of the Philippines, the number of nurses working abroad is estimated to be around 87,000. ${ }^{13}$ The main export destinations are outside the ASEAN region. They include Ireland, Kuwait, Libya, Saudi Arabia, the United Arab Emirates, the United Kingdom, and the United States. Hospitals and specialized recruitment agencies in these countries directly source their nurses from the Philippine labor market. Over the past few years, there has been a sharp increase in the number of medical schools offering nursing degrees. Several of these schools have adapted their course curricula to the needs of foreign markets. Other attractive characteristics of Filipino nurses include their command of English as well as their reputation for being industrious, warm and capable of adapting to other cultures. So far, there have been few concerns about domestic shortages of nurses in the Philippines, as there has always been a sufficient supply of newly graduating nurses.

For Indonesia, the main export destinations are other Islamic countries, especially countries in the Middle East (Saudi Arabia, United Arab Emirates) but also Malaysia and Singapore. Language and cultural affinity account for this geographic export pattern. Concerns about exports leading to domestic shortages are more pronounced than in the Philippines, as Indonesia's healthcare system is chronically understaffed.

Within ASEAN, the main host economies for foreign healthcare workers are Malaysia and Singapore and, to a lesser extent, Thailand. Interestingly, Malaysia is both a recipient and a sender of healthcare workers, with Malaysian hospitals hiring mainly Indian and Filipino nurses, and Malaysian nurses working in Singapore and Saudi Arabia. In 2001, there was a net outflow of about 450 nurses, which represented less than 3 percent of total nurses employed. The same holds for medical doctors. Over the past decade, private and public hospitals have hired several hundred doctors and medical specialists, partly to address a serious domestic shortage of doctors. At the same time, a significant number of Malaysian doctors have moved to higher wage countries-in particular, to Singapore.

\footnotetext{
${ }^{13}$ Unfortunately, no statistics are available on the number of returning nurses.
} 
Cambodia, Laos and Vietnam have, so far, not become significant exporters of healthcare workers. This reflects language barriers as well as less developed medical education systems in these three low-income countries.

\section{Existing trade barriers}

Notwithstanding the fact that trade in health services is already an important phenomenon in the ASEAN region, foreign service providers encounter a variety of barriers in supplying services to countries in the region. This section will offer an overview of these barriers. It will distinguish between three types of barriers: explicit policy barriers that directly restrict the supply of services by foreigners; regulatory measures that work to disadvantage foreign suppliers; and economic, cultural and reputational barriers that have a trade-impeding effect.

\section{Explicit policy barriers}

Explicit policy barriers are of greatest relevance for services supplied through commercial presence (mode 3) and the movement of individual service suppliers (mode 4). Governments generally do not restrict telemedicine or remote medical transcription services supplied crossborder (mode 1). Indeed, since this form of services trade is typically delivered via electronic networks, it may be technically difficult for governments to impose import limitations. Similarly, governments usually do not explicitly prevent domestic residents from seeking medical treatment abroad (mode 2).

As for commercial presence, key explicit policy barriers include foreign equity limitations, economic needs tests, and various performance requirements. Table 9 summarizes these barriers for the seven ASEAN countries in question. Interestingly, policy seems to be more liberal in the poorer countries relative to the richer countries. Cambodia, Indonesia, Laos, and Vietnam allow, in principle, for full foreign ownership in the sector, whereas Malaysia, the Philippines, and Thailand only allow minority foreign ownership. This difference in policy may partly reflect the desire of poorer countries to attract foreign investment as a means to develop their domestic healthcare systems.

Table 9 also presents information on the extent to which ASEAN countries have made commitments in hospital and related services under the WTO's General Agreement on Trade in Services (GATS). Only Cambodia and Malaysia have made commitments, so far. Cambodia locked in its liberal policy regime when it acceded to the WTO in 2003. Malaysia's Uruguay Round commitment reflects the Government's applied policy, although the foreign equity share in one hospital exceeds the 30 percent limit and the required economic needs test has not been used to deny foreign entry. Laos and Vietnam are currently in the process of acceding to the WTO. However, in its bilateral trade agreement (BTA) with the United States, Vietnam committed to full foreign ownership in the health sector, as long as certain minimum investment requirements are met (this commitment has also been offered to other WTO members in the course of Vietnam's accession negotiations). Laos made an even more ambitious commitment in its BTA with the United States, not scheduling any market access or national treatment limitations for health and medical care services. Finally, none of the seven countries studied 
here have made a commitment for health services under the ASEAN Framework Agreement in Services (AFAS).

Table 9: Explicit policy barriers and GATS commitments (Mode 3)

\begin{tabular}{|c|c|c|}
\hline & Explicit policy & GATS commitments \\
\hline Cambodia & $\begin{array}{l}\text { Full foreign ownership allowed; one director } \\
\text { must be Cambodian. }\end{array}$ & $\begin{array}{l}\text { No restriction, except at least one director for } \\
\text { technical matters must be Cambodian. }\end{array}$ \\
\hline Indonesia & $\begin{array}{l}\text { Conflicting policies; full foreign ownership } \\
\text { allowed according to investment policy; } 90 \\
\text { percent foreign equity limitation according to } \\
\text { Ministry of Health. }\end{array}$ & Unbound. \\
\hline Laos & Full foreign ownership allowed. & $\begin{array}{l}\text { Laos is in the process of acceding to the WTO. } \\
\text { US-Laos BTA grants full market access and } \\
\text { national treatment for health and medical care } \\
\text { services. }\end{array}$ \\
\hline Malaysia & $\begin{array}{l}30 \text { foreign equity limitation (though foreign } \\
\text { equity in one hospital exceeds } 30 \text { percent); } \\
\text { economic needs test; minimum of } 100 \text { beds. }\end{array}$ & $\begin{array}{l}30 \text { percent foreign equity limitation; economic } \\
\text { needs test; minimum of } 100 \text { beds. }\end{array}$ \\
\hline Philippines & $\begin{array}{l}\text { Foreign equity ownership limited to } 40 \\
\text { percent for hospitals; full foreign ownership } \\
\text { allowed for health maintenance organizations. }\end{array}$ & Unbound. \\
\hline Thailand & $\begin{array}{l}\text { Foreign equity ownership limited to } 49 \\
\text { percent; can be circumvented by assigning } \\
\text { "nominees”; compliance with local } \\
\text { regulations required. }\end{array}$ & Unbound. \\
\hline Vietnam & $\begin{array}{l}\text { Full foreign ownership allowed in principle; } \\
\text { economic needs test; transfer of technology } \\
\text { and training of local staff required. }\end{array}$ & $\begin{array}{l}\text { US-Vietnam BTA commits Vietnam to full } \\
\text { foreign ownership, but sets minimum investment } \\
\text { requirements. Vietnam is in the process of } \\
\text { acceding to the WTO. Third offer in services } \\
\text { reflects commitment under the BTA. }\end{array}$ \\
\hline
\end{tabular}

Source: National research studies (see footnote 2) and GATS schedules of commitments.

As for the movement of healthcare workers, explicit policy barriers vary from country to country. Among the richer ASEAN economies, Malaysia and the Philippines subject the entry of foreign medical professionals to economic needs tests. Certain professions, such as dentistry, are completely closed to foreign professionals. Market access in these countries is also granted on a preferential basis. For Malaysia, preferences take the form of bilateral agreements for the supply of nurses (with Albania, Bangladesh, India, Indonesia Myanmar, the Philippines, and Vietnam). In the case of the Philippines, there are numerous requirements for reciprocal treatment of Filipino professionals in foreign countries. Access of foreign healthcare workers to the Philippines is also subject to visa quotas set annually by the Department of Foreign Affairs. Thailand is, in principle, open to the entry of foreign professionals. However, few foreign professionals have entered the country, as they would need to pass a professional examination in Thai language (see below). 
Indonesia is largely closed to the entry of foreign healthcare workers. Limited exceptions only exist for occupational therapists. Cambodia, Laos and Vietnam do not seem to explicitly restrict the entry of foreign medical professions.

As for trade commitments, Malaysia made a mode 4 commitment under the GATS for a number of specialized medical professions (e.g., forensic medicine, neurosurgery, cardiothoracic surgery, plastic surgery). ${ }^{14}$ Cambodia, Indonesia, the Philippines, and Thailand did not make GATS commitments relating to the movement of health professionals. None of the seven countries studied has made a commitment in this area under AFAS.

\section{Regulatory measures}

The absence of explicit policy barriers is a necessary but not sufficient condition for foreign service providers to access domestic healthcare markets. In many cases, they face domestic regulatory measures that effectively put them at a competitive disadvantage. These regulatory measures differ across modes of supply.

In the case of telemedicine and cross-border medical transcription services (mode 1), countries typically have laws to protect the privacy of patient data. To the extent that data protection standards and enforcement practices are weaker in foreign jurisdictions, regulators may prohibit the sending of patient information to foreign countries and thereby effectively curtail services trade. In the case of the Philippines - the most significant exporter of medical transcription services in the region-privacy concerns have so far not inhibited services exports. Patient information is protected through service contracts between the importing hospitals in the US and the exporting transcription companies in the Philippines (most of which are US-owned). Nonetheless, privacy concerns may well become more important for cross-border services trade, as technology continues to widen the scope of tradable services and more countries participate in this form of international trade.

One of the most significant barriers to health tourism exports (mode 2) is the lack of portability of health insurance in foreign countries. This may not necessarily constitute a regulatory barrier. Private health insurers may voluntarily restrict coverage for treatments incurred in foreign countries. Even though treatment in foreign hospitals may offer opportunities for cost savings, insurers may be concerned about the quality of treatment in foreign hospitals and higher costs due to the need for follow-up treatments. But insofar as health insurance is provided by government-run schemes, the lack of health insurance portability may be considered a regulatory barrier. Indeed, Thailand, in its negotiations towards a free trade agreement with Japan, has requested that Japan's public medical insurance system cover the treatment of Japanese patients in Thai hospitals.

In the case of commercial presence (mode 3), foreign-owned hospitals in all ASEAN countries studied need to comply with all relevant domestic regulations, including requirements on location and minimum size, standards for medical equipment, qualification of medical personnel,

\footnotetext{
${ }^{14}$ In addition to the economic needs test, the commitment lists three national treatment limitations: practice only in private hospitals of at least 100 beds; practice to be only at a specified location and a change of location requires approval; the setting up of individual or joint group practices is not permitted.
} 
availability of emergency facilities and other matters. These regulations apply equally to domestic and foreign hospitals and therefore do not constitute a discriminatory barrier to trade. But to the extent that hospital regulations vary among ASEAN countries and foreign hospitals are unfamiliar with regulatory requirements abroad, these measure may place foreign operators at a competitive disadvantage.

Regulatory barriers are of great relevance for the movement of healthcare workers. Domestic regulatory authorities typically require that foreign doctors and nurses have at least the same level of qualification as domestic doctors and nurses. How competencies are assessed differs from country to country. In Thailand, interested foreign doctors have to pass professional examination in Thai language, which effectively shuts out foreigners. Since 1985, only seven foreign doctors were able to pass the examination and obtain a medical license. In the Philippines, qualification requirements are similarly restrictive. Interested foreign medical professionals need to pass the 'state licensure examination' and, additionally, must have permanently resided in the Philippines for at least three years prior to registration. Apparently, no foreign medical professional has so far applied for a permanent permit. ${ }^{15}$

In Malaysia, qualification requirements do not pose an equally severe barrier to the entry of medical professionals. Foreign doctors need to have at least five years of post-specialist experience in a recognized hospital, as determined by the Ministry of Health. Provided they can prove that no domestic doctor can fill an open position, Malaysian hospitals can typically process an application and hire a foreign professional within 12 months. Malaysia's less restrictive regulatory regime may be partly explained by the shortage of medical personnel described above.

Qualification requirements in Cambodia are also less restrictive compared to the Philippines and Thailand. Foreign doctors need to prove possession of a medical degree and have five years of relevant experience. Applications are examined by the Ministry of Health, though it is not known how many applications have been submitted and how many have been approved.

Regulatory entry barriers for nurses are typically less severe than for doctors. Still, recognition of nursing degrees can be important for determining the level of seniority and pay of foreign nurses. Filipino nurses moving to other countries sometimes are limited to junior positions or are paid lower wages than local nurses — an issue which the Philippines have raised in bilateral trade negotiations with Japan.

As a final observation, even though regulatory measures may have a trade-impeding effect that does not mean that they do not serve legitimate objectives. Certainly, no country would want to allow entry of any doctor who claims to be one. Yet two questions are important from a trade policy perspective. First, whether regulatory regimes unnecessarily impede trade, that is to what extent the same regulatory objectives could be met by less trade restrictive regulatory measures. And second, how trade can be promoted by pro-active regulatory cooperation between countries in a way that preserves regulatory goals. We will come back to these questions in Section VI.

\footnotetext{
${ }^{15}$ In both Thailand and the Philippines, special exceptions to these rules exist for doctors entering the country on a temporary basis as part of humanitarian missions.
} 
In addition to government measures, the entry of foreign service providers is constrained by a number of other factors. First, limited entry of foreign service providers in Cambodia, Laos, and Vietnam can largely be explained by their low level of economic development. The size of the private healthcare market in these countries is still too small to attract significant amounts of foreign investment-despite their openness to FDI. In addition, high income patients who can afford high quality medical care have the option of seeking treatment abroad. Similarly, foreign medical professionals have little economic incentive to move to these three ASEAN economies, because of low wages and better opportunities in other countries.

Second, the movement of healthcare workers and health tourism exports are held back by language barriers. Since doctors and nurses need to communicate with patients, knowledge of the host country's language is an essential requirement for the employment of foreign medical professionals. For patients seeking treatment abroad, knowledge of the local language is a less binding constraint, as many hospitals catering to foreigners offer their services in English (or Japanese). But it is still a factor affecting the choice of where to seek treatment. As described above, existing health tourism trade and movements of nurses in the ASEAN region already reflects language and other cultural affinities.

Third, for hospitals to attract foreign patients, especially from more developed countries, they need to build a reputation for high quality medical treatment. This is of particular importance for enticing foreign health insurers to cover treatment costs incurred by visiting patients. As already described, accreditation systems can be helpful in signaling quality to foreign patients and insurers, although many of these systems are confined to national jurisdictions. Marketing campaigns can be an important vehicle to advertise hospital service to foreign patients. However, it usually takes a number of years and substantial investments before a hospital establishes an international reputation.

\section{The gains and pitfalls from trade in health services}

As pointed out in the introduction, trade in health services creates both opportunities and risks. This section will review the key economic effects from greater openness in healthcare. Since these effects depend on the way in which services are supplied internationally, the discussion will proceed along the four modes of supply introduced in Section III.

\section{Cross-border trade and consumption abroad (modes 1 and 2)}

The gains from cross-border medical transcription services, telemedicine and health tourism are akin to the gains economists traditionally associate with international trade in goods. Differences across countries in endowments with capital, labor, and technology imply that some countries possess a comparative advantage in the supply of certain health services, meaning they can provide them more cheaply than others. Allowing trade in healthcare services can thus generate efficiency gains for both the importing and the exporting economies. Patients who seek medical treatment abroad and hospitals which outsource medical transcription to foreign service 
providers can realize significant cost savings. One recent study, for example, estimated that the United States would save $\$ 1.4$ billion annually if only one in ten patients were to go abroad for a limited set of low-risk treatments (Mattoo and Rathindran, 2005). Countries that export health services realize gains from specialization, allowing them to employ their capital and labor where they are most efficient and generating export revenues for the import of other goods and services.

As already pointed out, the comparative advantage of Malaysia, the Philippines, Singapore and Thailand in certain health services is founded on their endowment with a well-educated, but relatively cheap healthcare workforce, combined with access to modern medical technologies. The latter aspect highlights a second important benefit from trade: greater choice. Patients from poorer ASEAN countries and elsewhere are able to undergo treatment for certain conditions not available in their home countries. In addition, some hospitals in the ASEAN region (especially in Singapore) have developed a reputation for excellence in certain specialized medical fields, which attracts patients from around the world.

Notwithstanding these efficiency and choice gains, trade also has adverse effects. Any economic activity that experiences rapid growth due to export expansion will become dearer in the domestic economy. In principle, trade theory holds that economies as a whole gain despite rising prices for exported commodities. But even if economies as a whole gain, export expansion in the health sector may have important distributive consequences for domestic patients. In addition, the public good characteristic of healthcare alluded to in the introduction raises the question of whether economies as a whole could even be worse off by rapidly expanding health tourism exports.

Distributive concerns are particularly relevant for Malaysia and Thailand. In Thailand, private hospitals that treat foreign patients do not participate in social health insurance schemes. In addition to foreigners, they also serve middle and upper-income Thai patients, who pay out of pocket or are covered by private health insurance. Since they generate more revenue per patient, they can offer higher salaries to medical staff. This has diverted medical personnel away from public hospitals and private hospitals that serve Thai patients only (many of which participate in social health insurance schemes). By one estimate, an extra 100,000 patients seeking medical treatment in Thailand leads to an internal brain drain of between $240-700$ medical doctors. ${ }^{16}$ This has exacerbated shortages of medical professionals in Thailand, especially in the public sector and in rural areas. A related concern is that tertiary medical education in Thailand is provided by the public sector. Private exporting hospitals hire from the same pool of doctors as public hospitals, yet they do not share the costs of medical education.

Similar concerns exist in Malaysia. The rapid growth of private hospitals in the country has led to a drain of medical professionals away from the public sector, causing serious staff shortages and long waiting times in public hospitals. The inflow of foreign medical professionals has not alleviated domestic shortages in medical personnel (partly because Malaysian doctors and nurses have gone abroad, too). Greater numbers of foreign patients seeking treatment in Malaysia would put further pressures on the domestic healthcare system.

\footnotetext{
${ }^{16}$ See Pannarunothai and Suknak (2004).
} 
Foreign investment in hospital and related services can contribute in various ways to the reach and quality of health services. It may relax domestic capital constraints and alleviate supply shortages in the domestic healthcare system. Foreign hospitals may bring advanced medical knowledge and specialized equipment, offering new treatments to domestic patients. The host country may also benefit from links that foreign healthcare providers may have established with medical schools abroad, which could stimulate research collaborations and the provision of specialized training. Foreign entrants may also transfer valuable organizational skills and managerial know how, gained through experience abroad. Being part of multinational hospital networks offers additional benefits. Bangkok Hospital, for example, cites increased bargaining power vis-à-vis suppliers of medical equipment and improved quality control mechanisms as key advantages of operating a large network of hospitals. The contribution of FDI could be especially important in the poorer ASEAN economies with underdeveloped health systems. This explains why Cambodia, Laos, and Vietnam impose few policy barriers to the establishment of foreign hospitals - though the small size of their healthcare market remains a binding constraint to attracting more FDI.

The more controversial aspect is to what extent foreign investment may exacerbate inequalities in the domestic healthcare system. As described above, foreign hospitals typically cater to middle and upper-income patients and almost exclusively locate in urban areas. That also means they can offer the most attractive pay package to medical professionals, leading to the internal brain drain phenomenon discussed above. There is no evidence, however, whether such adverse effects have been important in the ASEAN economies studied. That may partly be because the extent of foreign participation in countries' healthcare sectors has so far been small.

In addition, as described in Section II, existing healthcare systems are already tilted towards more affluent patients who are covered by private health insurance or pay for treatment out-ofpocket. Foreign investment may improve the quality and choice for those who can afford private health services. This would, indeed, worsen inequality, but it would not necessarily affect access to the health system by those patients which rely on public provision or public insurance schemes. A related consideration is that foreign entry may induce domestic patients who in the past sought medical treatment abroad to stay at home. Again, such an outcome would worsen inequality in the national provision of healthcare, but it would not necessarily worsen inequality in the consumption of health services by domestic patients.

In the end, the net contribution of foreign investment to equity and access also depends on the type of foreign entry and accompanying policy choices. If entry takes the form of acquisition and domestic medical personnel is scarce, internal brain drain effects may be more pronounced. By contrast, if foreigners build new hospitals and bring along doctors and other medical staff, their investment may help alleviate pre-existing shortages.

\section{Movement of healthcare workers (mode 4)}

The gains from nurses and doctors moving from one country to another are at first similar to the ones outlined for cross border trade and health tourism. The movement of health workers from 
low-wage countries to high wage countries can improve economic efficiency. For receiving countries, the benefit usually takes the form of alleviating shortages of domestic medical personnel-a growing problem in many middle and high-income countries. In the case of medical specialists, additional benefits can arise in the form of new treatments becoming available and incoming doctors transferring medical knowledge. For the sending countries, the welfare effects depend crucially on where foreign healthcare workers spend their income. If a significant share of earnings is remitted home-as is the case for Filipino nurses working abroad - the sending country is likely to benefit, too. Otherwise, the sending country will experience a net economic loss.

Another important question is how the outflow of healthcare workers affects the supply of medical personnel in the sending countries. As described in the previous section, the outflow of nurses from the Philippines has so far not led to any domestic shortages. By contrast, the net outflow of nurses from Indonesia and Malaysia seems to have exacerbated already existing shortages of nurses in the country.

Finally, a key consideration for the sending country is whether the movement of healthcare workers is of a temporary or permanent nature. In fact, as pointed out in Section III, this is precisely what distinguishes trade in services from migration. If nurses and doctors return to their home countries after a number of years, concerns about domestic supply shortages may be less severe. Returning medical professionals may also bring with them new skills and capital that can be invested in the domestic economy. If, by contrast, labor movement is permanent, there is the risk of substantial human capital losses with damaging long-term effects on social and economic development.

\section{Policy implications}

Trade policy in healthcare cannot be considered in isolation from domestic healthcare policy. The latter involves defining the roles or the public and private sectors in providing and financing healthcare. In doing so, governments face difficult choices. We highlight four key domestic policy challenges.

First, few countries can afford state-of-the-art medical services for every citizen. Most high income and some middle-income countries can provide universal healthcare covering selected treatments. In low-income countries, access to healthcare services will often be unavailable or restricted for certain population segments. At the same time, some richer patients in all countries will always be able to afford high quality medical care, relying on private insurance or out-ofpocket financing. Private financing can alleviate the healthcare burden of the public sector. But the emergence of a two-tier healthcare system can also undermine governments' efforts to provide healthcare to those who cannot afford it. On average, richer patients and patients private insurers are willing to insure tend to be healthier. Their dropping out of public insurance schemes may, on balance, diminish the funds available to treat the poor. In addition, high quality providers may draw away scarce medical personnel-especially the most talented doctorsaway from hospitals serving poor patients. Few countries have left the provision of health services for those who can afford entirely to market forces. At the other end of the spectrum, no 
country has entirely thwarted the emergence of a two-tier system. Governments need to decide where to draw the line and what levels of inequality are deemed acceptable.

A second and related challenge is the choice of mechanisms to promote universal-or at least wider-access to health services. This is a priority in most ASEAN countries, where existing healthcare systems are biased towards more affluent patients in urban areas (see Section II). Again, difficult trade-offs exist. Providing basic healthcare services for free promotes access to healthcare by those who truly cannot afford. But free universal healthcare is beyond the means of most state budgets. In addition, free access benefits those middle-income patients who can afford to contribute and it may encourage overuse of the public healthcare system (so-called moral hazard problems). Since patients derive a private benefit from medical treatment, a system of user fees would establish better economic incentives. But user fees may precisely cut off from the system those who truly cannot afford. A possible way out is the establishment of health equity funds that subsidize user fees to those truly in need. An example of how such a fund operates in Cambodia is described in Box 1. If properly run, health equity funds can maximize the utilization of limited public resources to the benefit of the poor.

The reach of health services can also be promoted through cross-subsidies. For example, user fees or insurance contributions can be fixed to vary with patients' income. A more implicit form of cross-subsidy is to require doctors to spend a certain time period in public hospitals or remote areas, before they can be hired by the private sector-as is practiced in Cambodia and Thailand. Similarly, private hospitals may be required to reserve a certain share of beds to poor patients. Such requirements can also be extended to foreign hospitals_-as is practiced in Indonesia. These forms of service obligations are attractive regulatory tools for resource-strapped governments, as they do not involve any direct budgetary outlays. But relative to direct patient subsidies in the form of health equity funds, they create economic distortions (and may pose a disincentive to FDI).

\section{Box 1: The operation of a health equity fund in Cambodia}

As part of a 'new deal' on improving healthcare in the poor rural district of Sotnikum in Cambodia, a special health equity fund was established in 2000. Several features of this fund seek to overcome traditional problems encountered in improving access to health services by the poor. First, assistance from the fund does not only cover the user fees charged by the district hospital, but also transportation costs and other expenditures that prevent poor people from seeking medical treatment. Second, the management of the fund was subcontracted to a local social welfare NGO. Experience has shown that entrusting such a fund to the hospital itself can be problematic, as hospitals would pay their own user fees and would have little incentive to target those truly in need of assistance. Third, candidates for assistance are not only identified by referral from the hospital, but also through active recruitment by the staff of the managing NGO. Fourth, eligibility for assistance is determined through rigorous interviews, which collect data on applicants' income, assets, and other variables relevant for assessing the degree of impoverishment. The level of financial assistance is determined on a case-by-case basis.

After four years of operation, the health equity fund can be considered a success. On average, 40 percent of the district hospital's inpatients have received some financial assistance. Monitoring has confirmed that beneficiaries were actually poor. A considerable number of patients were from poor households that would not have sought medical care without financial assistance. Another beneficial effect is that poor 
patients are less likely to seek treatment from informal private practitioners, where the quality of services is generally poor. Finally, a large share of the fund goes to the hospital in the form of user fees. This contributes to the financial base of the hospital and promotes the development of the public hospital system.

Source: Meessen and Ir (2005).

A third important challenge is the development of adequate human resources, in terms of both numbers and skills. Experience has shown that as countries grow richer the demand for health services grows even more rapidly. Often, the supply of new graduates cannot keep up with demand. As described in Section II, shortages of medical personnel exist in one form or another in most of the ASEAN countries considered here. Addressing these shortages requires investments in medical education and sufficient pay incentives for students to enter the medical field. Since there is a long time lag before medical students become practicing doctors, governments need to plan for the long term.

A fourth challenge of greatest priority to the poorer ASEAN countries is the development of regulatory capacity in the health care sector. As described in Section II, regulations in Cambodia, Indonesia, Laos and Vietnam are both underdeveloped and inadequately enforced. Patients in these countries are adversely affected by poor quality medical treatment and sometimes even suffer abusive practices. Strengthening regulatory systems requites dedicated efforts by governments, combined with technical assistance from richer countries and specialized international health agencies.

The effects of trade policy need to be assessed in the light of the strategies governments have in addressing the challenges outlined above. In some areas, trade reforms can be helpful in advancing objectives set by governments. In other areas, trade can make existing problems worse. The effects will also differ across countries, as already illustrated in the previous section. With these considerations in mind, the remainder of this section explores two questions. First, how are domestic policy and trade policy best sequenced? And second, what is the role of international agreements and cooperation within ASEAN?

\section{How are domestic policy and trade policy best sequenced?}

In Malaysia and Thailand, the growth of private hospitals has provoked a brain drain of health professional from the public sector towards the private sector. Greater mode 2 exports would channel more healthcare resources in the private sector towards servicing foreign and high income local patients, to the detriment of low and middle-income patients. Ideally, this problem needs to be addressed before actively promoting mode 2 exports. There are three ways in which supply shortages could be alleviated: (i) invest in the education of more health professionals; (ii) stem the brain drain from the public sector and rural areas by appropriate incentives; and (iii) import foreign healthcare professionals.

Increasing the supply of healthcare professionals require resources and time. Currently medical education in all ASEAN countries is heavily subsidized by the government. Given that the private sector is also the beneficiary of medical graduates, it makes sense that they should also 
share some of the cost. This may be done in-kind through private participation in the training of medical students; or else through tuition refunds. In Thailand, it is compulsory for medical graduates to work in the public sector for three years after graduation from state universities. However, those who opt to move to the private sector in less than three years are made to pay a fine of USD 12,000. However, this fee bears no relationship to the opportunity cost to the public health system. At least the fee should reflect the cost of education and the productivity foregone until a new graduate is ready for work. Given the long training period for physicians, advanced planning is required should a government decide that promoting mode 2 trade is the way forward. For other types of medical personnel, the period of training is shorter and private provision already exists-witness the success of nursing schools in the Philippines.

One of the most worrying repercussions is the indirect impact on medical doctors in rural areas where healthcare resources are already scarce. Several measures have been used by the Thai government over the years in an attempt to improve the distribution of healthcare personnel. These include: hardship allowances; rural recruitment and placement; career development incentives for physicians in rural areas; and relaxing barriers to foreign physicians practicing in the rural areas. In many countries, physicians work in both the public and private sectors. This type of sharing arrangement could be encouraged to avoid permanent drain from the public to the private sector and could be justified by the public sector's investments in medical education.

Similar sequencing issues arise in the case of FDI opening. If there are concerns that the entry of foreign hospitals will cause an internal brain drain —or exacerbate an already existing internal brain drain problem - full market opening may need to be postponed. Investments in the education of more health personnel could resolve such conflicts, but will likely take time. In the meantime, brain drain effects could be attenuated by appropriate incentives and obligations for doctors to practice in low-income and rural areas. Alternatively, governments could require foreign entrants to bring in their own medical personnel. Having said this, it is worth reemphasizing that internal brain drain effects are not automatically associated with foreign entry-especially in view of the fact that many healthcare systems in the ASEAN region are already skewed towards those who can afford healthcare and those who live in cities.

Finally, long-term human resource planning is also necessary before countries choose to actively promote the sending of healthcare workers abroad. Better access to foreign employmentnegotiated, for example, through trade agreements-increases the opportunity cost of healthcare workers to stay at home. As long as there are sufficient numbers of newly graduating or returning medical professionals ready to serve the domestic market, this does not pose any problem. But given that salaries in most ASEAN countries are significantly below those paid by the United States, the United Kingdom or oil-rich countries in the Middle East, domestic shortages are bound to arise. A case can be made for actively managing the outflow of healthcare workers - in particular, to stop exports when there are domestic shortages. However, this is likely to require the cooperation of trading partners, as it may be difficult for governments to stop workers from moving abroad.

The role of international agreements and cooperation within ASEAN 
In principle, trade agreements offer three different benefits to participating members. First, they offer a forum for reciprocal bargaining. Governments that see benefits from own market opening may find it easier to liberalize trade in the context of international agreements. This is because domestic opposition to liberalization may be overcome more easily if a government can show market access gains in other negotiating areas. Second, a commitment under a trade agreement, even if it only locks in status quo policies, can lend credibility to the domestic policy regime. Once committed, it is difficult for governments to reverse market opening policies, providing foreign investors and traders with some assurance of policy stability. Third, trade agreements offer a forum for regulatory cooperation. As pointed out in Section IV, the removal of explicit trade barriers may be insufficient for foreign service providers to enter the domestic market. Often, trade can only take off if countries' regulatory systems are made compatible.

To what extent have trade agreements delivered on these benefits? In which trade forummultilateral or regional-are they best realized? And what are areas for regulatory cooperation that could promote deeper integration in the healthcare sector? We will consider these questions in turn.

As for the first question, it seems fair to say that trade agreements have so far played only a very minor role in stimulating trade in health services in the ASEAN region. Where ASEAN governments have opted for liberal trade policies, they have done so unilaterally. In particular, the scope and depth of trade commitments made by ASEAN countries at the WTO and under AFAS have so far been limited (see Section IV). In the WTO, only Cambodia and Malaysia have scheduled a commitment in the health sector. This largely reflects the broader lack of ambition in multilateral services negotiations so far.

One exception to this pattern has been the case of countries that have acceded to the WTO in recent years. Negotiations for accession to the multilateral trade body are inherently asymmetric, as acceding governments have to satisfy the demands of the existing membership without being able to ask for reciprocal trade concessions. This has resulted in aspiring members making commitments that are wider and deeper than the ones of existing WTO members at similar levels of development. Thus, Cambodia has locked in its liberal trade policies in healthcare when it acceded to the WTO in 2003. Vietnam is still in the accession process, but the Government's third offer on services includes a comparable commitment. Laos is at an even earlier stage in the accession process and has not yet made any offer in the service sector. But the Government may well come under pressure to extend the liberal commitment in services (including in healthcare) it made in its bilateral trade agreement with the United States to other WTO members (see Table 9).

At the regional level, the four negotiating rounds under the ASEAN Framework Agreement in Services (ASEAN) have so far not resulted in commitments in the health sector. However, healthcare was identified as one of eleven priority sectors for integration at the 2003 Summit of ASEAN Economic Ministers in Bali. 
If ASEAN countries were willing to commit to market opening in healthcare in future trade negotiations, should they do so at the multilateral or regional level ${ }^{17}$ No general answer can be given. The benefit of engaging in the WTO is that trade commitments are made on a nondiscriminatory or most-favored nation (MFN) basis. This is economically advantageous, as services providers from around the world will enjoy the same market access conditions, favoring entry of the most efficient suppliers.

At the same time, there are also reasons for negotiating at the regional level. One is that bargaining may be more productive among a smaller set of countries. The WTO now has 148 members at all levels of development and the multilateral trade agenda has much expanded since the early GATT days. Trade negotiations at the multilateral level therefore tend to be complex and time-consuming. Indeed, progress in the current multilateral services negotiations under the Doha Development Agenda (DDA) has been limited, so far. ${ }^{18}$

For countries ready to commit to market opening in services, a bilateral or regional forum may deliver quicker results. In addition, if service providers from within the region are at an infant stage, regional market opening may, in theory, offer learning externalities that can enable these providers to become more efficient and eventually face global competition. But regional liberalization may also entail economic costs, mainly in the form of second-based service providers entering the domestic market. Notwithstanding these considerations, the conclusion of trade agreements is also driven by political imperatives, which in recent years have favored the negotiation of bilateral and regional agreements.

There is little controversy that regional agreements have an important role to play in the area of regulatory cooperation. Making regulatory regimes more compatible seems neither feasible nor desirable at the multilateral level. The WTO currently has 148 members, at every level of development and with a wide variety of legal and regulatory systems. While the ten ASEAN countries are not a homogenous group either, there does appear to be scope for increased cooperation in the health sector —as is already happening in many other fields.

The national research studies for the seven ASEAN countries identified a number of specific areas for regulatory cooperation that could be pursued at the ASEAN level:

- Promoting health tourism exports. Notwithstanding the need for appropriate policy sequencing as outlined above, there are a number of initiatives that could expand trade within the region. First, an ASEAN-wide framework for the portability of health insurance could be developed, which would seek to address the concerns of public and private insurers in covering medical expenses occurred in other ASEAN countries.

\footnotetext{
${ }^{17}$ For a more detailed discussion of the choice of regional versus multilateral agreements in services, see Mattoo and Fink (2004).

${ }^{18}$ The climate for negotiating trade in health services under the GATS also does not appear to be favorable. Some NGOs have raised concerns that GATS commitments in the health sector would encroach on national sovereignty and promote inequitable health systems. In the current negotiating round, this has led the European Communities to refrain from making market-opening requests in this sector to developing countries. Compared to other service sectors, such as financial and express mail delivery services, there also do not appear to be strong private sector lobbies pushing for liberalization.
} 
Second, the development of rules on the privacy and confidentiality of patient information would help assure patients that foreign hospitals treat such information responsibly. It could also encourage the exchange of patient data between hospitals in different countries, when this is necessary for optimizing medical treatment. Third, while there is already an ASEAN initiative to promote visa-free travel among its member countries, there is scope to further minimize visa requirement for traveling patients—for example, for patients seeking treatments requiring a stay longer than the maximum number of days allowed in tourist visas. Fourth, an ASEAN-wide system for the accreditation of high quality hospitals could be developed. This could help hospitals overcome reputational barriers to greater health tourism exports.

- Managing the movement of healthcare workers. An ASEAN facility could be created that would monitor shortages and surpluses of medical personnel in different ASEAN countries. This could help policymakers evaluate where the movement of healthcare workers is warranted and where it exacerbates existing shortages. In addition, a special ASEAN visa — not necessarily limited to healthcare workers - could be developed that would be truly temporary in nature. Such a visa could address concerns in host countries that foreign workers will stay permanently and, at the same time, reduce negative brain drain effects in home countries. Where the movement of healthcare workers is considered desirable, it can be actively promoted through the harmonization of professional standards and the conclusion of agreements recognizing foreign qualifications. The short term movement of medical specialists for individual treatments could be promoted by developing a framework for malpractice insurance of out-ofjurisdiction medical personnel.

- Improving the quality of health services and medical training. The transfer of medical knowledge could be advanced by encouraging exchanges of hospital staff within the ASEAN region. Skills transfers could also be promoted by region-wide training initiatives and the harmonization of course curricula, especially for new medical technologies. In the long term, cooperation on training could also contribute to increased mobility of medical personnel in the region. Finally, regulators could exchange best practices in developing and enforcing medical service standards, which could be of particular benefit to the poorer ASEAN countries.

Several of the proposed regulatory initiatives would require the direct involvement of the private sector and medical associations. The role of ASEAN governments in these cases would be to provide the forum and set the direction for cooperation among those entities. In addition, in some areas regulatory cooperation may still not be feasible at the regional level. For example, it may not be realistic to draw up region-wide mutual recognition agreements (MRAs) for medical professionals. But developing regional frameworks for regulatory cooperation could help promote feasible cooperation at the bilateral level and ensure such cooperation could in the longer term be extended to other ASEAN members.

As part of ASEAN's effort to advance integration in the so-called priority sectors, the Government of Singapore has developed a Roadmap to advance the region-wide integration of 
the healthcare sector. ${ }^{19}$ This Roadmap was adopted by ASEAN Trade Ministers in November 2004 and incorporates many of the recommendations outlined above. Interestingly, the one area that has received relatively little attention in the Roadmap is the promotion of health tourism exports. In particular, while the streamlining of visa requirements for foreign patients is recognized, no measures are proposed to promote the portability of health insurance.

As a final note, while ASEAN provides a geographic and political foundation for regulatory cooperation, for at least some countries in the region there are likely to be large pay-offs from pursuing such cooperation with countries outside the region. As described in Section III, health services and healthcare workers are exported in large quantities to the United States, the United Kingdom, Japan, and countries in the Middle East. Indeed, cooperation on certain regulatory aspects has already taken place in the context of bilateral free trade agreements that ASEAN countries have signed in recent years.

\footnotetext{
${ }^{19}$ The sectoral initiative in healthcare is not limited to the integration of service markets, but also encompasses the promotion of trade in healthcare goods (for example, medical equipment, pharmaceutical products) as well as cooperation on questions of technical standards, intellectual property protection.
} 


\section{Concluding remarks}

ASEAN governments have set themselves the goal to progressively liberalize trade in health services in the region. From an economic perspective, opening healthcare markets promises substantial economic gains. Yet it may also intensify existing challenges in promoting equitable access to healthcare. In a way, trade may raise the stakes of domestic policy reforms. It may help focus policymakers' minds and create new opportunities for improving affordable access. But it may also lead to outcomes from which only the better-off will benefit.

Pursuing integration regionally, rather than through unilateral liberalization, holds certain advantages. Every country has something to gain from collective action-whether the prospect of greater exports or the promise of regulatory capacity building. This may help overcome domestic resistance to market opening - for example, from protectionist medical associations. In addition, deeper integration requires pro-active cooperation between governments, which by definition cannot be pursued unilaterally. Still, delivering on the recently adopted ASEAN Roadmap on Healthcare will be no small feat. ASEAN's past experience in promoting deeper integration points to the difficulties posed by differences in regulatory regimes and levels of economic development.

Economic research on the effects of liberalizing trade in health services is still in its infancy. In particular, more studies are needed which empirically assess the impact of trade reforms on key healthcare performance indicators. Such research would improve policymakers' understanding on what works in which circumstances and could thereby contribute to improving the design of trade reforms. 


\section{References}

Abidin, Mahani Zainal, Rokiah Alavi and Sazalina Kamaruddin. (2005). "GATS and Liberalization of Healthcare Services in Malaysia.” Draft manuscript.

Arunanondchai, Jutamas. (2005). “Trade in Health Services: the Case of Thailand.” Draft manuscript.

Akhmad, Rizal Shidiq. (2005). “Indonesia: Health Services.” Draft manuscript.

Chea, Samnang. (2005). “Trade Liberalization and Health Services in Cambodia.” Draft manuscript.

Leebouapao, Leeber. (2004). “Liberalization of Trade in Health Services in the Lao PDR.” Draft manuscript.

Meesen, Bruno and Por Ir. (2005). “Overcoming Barriers: Health Equity Fund in Cambodia.” Development Outreach, May 2005 (Washington, DC: The World Bank Institute).

Mattoo, Aaditya and Carsten Fink (2004). "Regional Agreements and Trade in Services: Policy Issues.” Journal of Economic Integration. Vol. 19, No. 4, pp. 742-779.

Mattoo, Aaditya and Randeep Rathindran. (2005). “Does Health Insurance Impede Trade in Healthcare Services?” Mimeo. (The World Bank).

Pannarunotai, S. and K. Suknak (2004). “The Impact of Health Services Liberalization on Thailand.” Paper presented at the $27^{\text {th }}$ Annual Symposium of Thammasart University.

Avila, John and George Manzano (2005). “Trade in Health Services: the Philippine Case.” Draft manuscript.

Thang, Nguyen Chien. (2005). “Vietnam’s Health Sector in Reform and Services Trade Liberalization.” Draft manuscript.

Thammarangsi. (2003). "Human Resources for Health: What Can We Learn From National Census?” Paper presented at the International Health Policy Programme, Journal Club on December 12, 2003.

Timmermans, Karin. (2002). “GATS, Trade, Health and Services.” Report of an ASEAN Workshop on the GATS Agreement and its Impact on Health Services. Published by the Association of Southeast Asian Nations, the Director General of Medical Care, Indonesia, and the World Health Organization.

World Health Organization (2005). World Health Report 2005. (WHO, Geneva). 
World Health Organization. (2005). Global Health Atlas of Infectious Diseases. (WHO, Geneva).

World Health Organization. (2005). Global Atlas of the Health Workforce. (WHO, Geneva). 